\title{
ORAL GRAFT-VERSUS-HOST DISEASES
}

\author{
Maria Elvira Pizzigatti Correa', Fernanda de Paula Eduardo², Leandro Dorigan de Macedo³, Leticia \\ Melo Bezinelli², Paulo Sérgio da Silva Santos ${ }^{4}$, Héliton Spindola Antunes ${ }^{5}$ \\ 1 Oral Medicine Ambulatory, Hematology and Hemotherapy Center, University of Campinas, Campinas, Brazil. \\ 2 Hospital Israelita Albert Einstein, São Paulo, Brazil - 3 Dentistry and Stomatology Division, Ophthalmology, Otolaryngol- \\ ogy and Head and Neck Surgery Department, Clinical Hospital of Ribeirão Preto School of Medicine, São Paulo University, \\ Ribeirão Preto, SP, Brazil - 4 Department of Stomatology, Bauru Dental School, USP-University of São Paulo, Bauru, SP, Brazil. \\ 5 Clinical Research Division, National Cancer Institute of Brazil, Rio de Janeiro, Brazil (INCA).
}

\begin{abstract}
The management of graft versus host disease (GVHD) requires a multidisciplinary team, including dentists among others professionals. In 2015 to standardize treatment approaches the Brazilian Society of Bone Marrow Transplantation published recommendation on the management of oral GVHD. Here we update these recommendations including the results of studies published after 2015.
\end{abstract}

\section{INTRODUCTION}

Graft-versus-host disease (GVHD) is a common complication in patients undergoing allogeneic hematopoietic stem cell transplantation (HSCT) and is responsible for high morbidity and mortality [26]. GVHD can present in acute and chronic form and usually involves several organs such as: eyes, mouth, skin, liver, intestine and lungs.

The involvement of the mouth in acute GVHD is less frequent than in chronic GVHD, but no less important. Usually in both situations, the oral manifestation of GVHD implies in pain, difficulties on speech, and restriction of food intake, which imply in decrease in quality of life $[18,19]$

There are few published papers addressing the manifestation and treatment of oral acute GVHD. In the other hand, for oral chronic GVHD, there are many papers addressing its clinical and histopathological characteristics and management.

This consensus aims to update the previous recommendations of the 2015 Consensus of the Brazilian Society of Blood Marrow Transplantation on the management of oral GVHD, throughout the literature review of papers published after 2015.

\section{METHOD}

A systematic literature review was carried including papers published after 2015 to 2020 . A bibliographic search was carried out using the Pubmed database, including full papers written in English, Spanish or Portuguese. The research was directed to the location of descriptors in titles, abstracts and $\mathrm{MeSH}$ of publications with help descriptors (GVHD OR Graft vs Host Disease AND (therapy OR treatment OR treating) AND (Oral Manifestations OR Mouth OR buccal).

\section{RESULTS}

The search resulted in a total of 44 publications, 4 (9\%) were excluded after reading the titles. The 40 selected papers were distributed by the six revisors, from which the data used in this study were extracted.

\section{ACUTE ORAL GRAFT-VERSUS-HOST DISEASE (GVHD)}

Although the mouth is not considered a target organ, oral manifestations of acute GVHD can be present in about $0.8 \%$ of patients undergoing allogeneic hematopoietic stem cell (HSCT) transplantation who have the acute systemic GVHD.[7, 18, 38]

The diagnosis of acute oral GVHD can be considered as a diagnosis of exclusion. Clinically, it is characterized by the presence of erythema, inflammation, nonspecific ulcerations, atrophy of the oral mucosa and redness of the lips, coinciding with neutrophilic grafting. It is important to point out that, although the oral manifestations of acute GVHD resemble those of oral mucositis, however, oral mucositis is re- 
lated to the toxicity of the conditioning regime and it usually presents a resolution prior to or coinciding with neutrophilic grafting $[15,18,21,32]$.

Infections related to the Herpes viridae family are often found in the oral cavity and are related to the degree of immunosuppression induced by the conditioning regime [15, 36, 37]. Clinically herpetic viral lesions in the oral cavity are characterized by ulcerations and pain and may be present even when using antivirals prophylaxis. These injuries are related to increased morbidity $[9,36]$. The diagnosis of oral viral infection is usually clinical, but it and can be complemented with a cytological exam (Papa Nicolao), or PCR for Herpes virus.

\section{TREATMENT}

The treatment for oral acute GVHD is mainly topical that can be associated with the systemic treatment protocol for acute GVHD. Mouthwashes with corticosteroids with dexamethasone $(0.1 \mathrm{mg} / \mathrm{mL})$ and clobetasol $(0.5 \mathrm{mg} / \mathrm{mL})$ associated or not with tacrolimus (tracolimus $0.1 \%)[18,27]$ can be use with good response treatment. Patients should be instructed to hold the medication for 5 minutes in the mouth and then, spit out the medication. Food intake, oral hygiene should be avoided for 10-15 minutes after the mouthwash.

The prophylactic use of antifungals is recommended when using mouthwashes with corticosteroids, due to the increased risk of fungal infection. Usually, it is recommended the use of mouthwash with subsequent swallowing of suspension of nystatin $[32,35]$.

There are one study showing the use of low power laser therapy for treatment of acute GVHD [30] and so far, no recommendation can be done for this treatment modality.

\section{CHRONIC ORAL GRAFT-VERSUS-HOST DISEASE (GVHD)}

The incidence of chronic oral GVHD is approximately $70 \%$ to $83 \%$ of patients submitted to allogeneic Hematopoietic Stem Cell Transplantation (HSCT).[22, 24] These manifestations may involve the entire oral mucosa, the labial mucosa and even the major and minor salivary glands.

Chronic oral GVHD is clinically characterized by the presence of white lacy lesions similar to oral lichen planus (lichenoid lesions), erythema, inflammation and atrophy of the mucous membranes and also by the presence of oral ulcerations. These changes can be observed in all sites of the oral cavity. Clinically, it can be observed as a single or multiple lichenoid lesion, isolated or associated with redness and ulcer- ation [14, 32]. In the perioral tissues, chronic GVHD can lead to sclerotic lesions and, consequently, to a decrease in mouth opening. $[6,14,35]$

Chronic GVHD in salivary glands can occur regardless of clinical manifestations in the oral mucosa. $[2,16,34]$. The dryness of the oral cavity can be assessed clinically during the inspection of the oral cavity.[2] Clinical criteria of hyposalivation such as adherence of the wooden spatula to the cheek mucosa, absence of salivary lake in the sublingual region, in addition to the presence of labial dryness can be useful for the diagnosis of dry mouth. Xerostomia can be assessed by the patient's complaint about the needs of fluids to facilitate the ingestion of dry foods. [2, 23]

In addition to the salivary glands, the salivary ducts are also affected by chronic GVHD, which can lead to the formation of pseudocysts of mucous retention (mucocele). Patients can report the formation of small cysts in any region of the mouth, but especially the hard palate, when stimulated by food intake. Ulceration can replace the pseudo cyst when it broken. [32]

In addition to changes in the structures of the salivary glands, and consequently, in the salivary flow, biochemical and proteomic changes in saliva have been reported. $[3,5,17]$

Usually, salivary changes do not respond to systemic treatment of chronic GVHD and it may persist as late effects. $[2,4,5,8,34]$ Persistent and late changes in saliva are associated with an increased risk of oral infections, especially fungal infections. In addition, they are associated with an increased incidence of dental caries and periodontal disease.[5, 10, 14, 28, 31] Salivary changes associated with changes in the oral microbiota may be associated with the presence of dysgeusia in these patients.[33]

\section{EVALUATION CRITERIA}

The assessment of chronic GVHD activity as well as the criteria for assessing treatment response were published by the National Institutes of Health Consensus Development Project on Criteria for Clinical Trials in Chronic Graft-versus-Host Disease: NIH Consensus in 2015.[19, 22]

Diagnostic signs and symptoms for chronic oral GVHD include the presence of lichen-like lesions (lichenoid lesions), characterized by the presence of lacy white lines on the oral mucosa. These changes are typically seen in the buccal mucosa and tongue but can be present in the entire oral mucosa and even in the labial vermilion. The lichen-like lesions may or may not be associated with erythema or ul- 
cerations, which are not considered as diagnostic features for chronic oral GVHD.[19]

The presence of white plaque without lichenoid characteristics are no longer considered as a clinical diagnostic criteria for chronic oral GVHD. However, these lesions must be considered, evaluated and biopsied, due the high risk of malignant transformation.[19, 25]

Distinctive signs and symptoms for chronic oral GVHD include hyposalivation, presence of mucous retention cyst (mucoceles), oral mucosa atrophy, ulcerations and pseudomembranous ulcerations. In the presence of ulcerations and oral inflammation, fungal, viral or bacterial infections, as well as neoplastic lesions, should be excluded.

Signs and symptoms found in both chronic and acute GVHD are referred as common features and include the presence of inflammation and atrophy in the oral mucosa, erythema and pain.[22]

The objective assessment of the therapeutic response in the oral cavity considers the presence of erythema in the mucosa (color intensity and percentage of the area involved), lichen-like lesions (percentage of the area involved); ulcerations (percentage of the area involved) described on an evaluation scale ranging from 0-12 graduation points. [22]

The subjective evaluation of the therapeutic response includes the presence and intensity of sensitivity to spices, foods, liquids or flavors. This assessment should be made in consideration of the patient's perception during the last week prior to the assessment and is described on a scale of $0-10$. For children, the same issues must be addressed, however a sensitivity scale between 0-3 must be used.[22]
Topical treatment of chronic oral GVHD aims to improve symptoms (mainly pain, tenderness and dry mouth), maintain oral functionality and restore mucosal integrity. This can be associated with systemic immunosuppressive treatment, mainly in refractory or difficult to control cases (figure 1). However, special care must be taken when using topical corticosteroids, mainly due to the increased risk of developing oral infections mentioned at the beginning of the chapter.

The performance of oral hygiene during all phases of treatment is extremely important and should be performed after meals and after topical use of corticosteroids. However, due to the variation in the presentation of chronic oral GVHD and the presence of chronic oral pain, oral hygiene must be adapted to the individual conditions of each patient. The use of $0.2 \%$ neutral sodium fluoride to prevent tooth decay in the form of mouthwash can be indicated as prophylaxis.[11, 26, 27, 32, 35]

Since the publication of the NIH consensus in 2015, new treatment options for chronic GVHD with oral involvement have been published. These protocols are directed to cases of chronic GVHD refractory to the use of systemic corticosteroids and to calcineurin inhibitors and include Tocilizumab,[21] Ruxolitinib. $[1,20]$ As topical treatments for chronic oral GVHD associated or not with systemic treatment, the use of platelet rich fibrin gel (PFR) [29] and, low-power laser therapy have been reported with satisfactory results, but with low scientific evidence. $[12,13,30]$

A list of topical management of oral GVHDC is shown in figure 1 (Adapted from Carpenter et al, 2015[6] and Wolff et al., 2011[39]

FIGURE 1-Supportive therapy for the treatment of oral chronic GVHD

\begin{tabular}{|c|c|c|c|c|c|}
\hline Indication & Preparation & Agent & Concentration & Rating & Comments \\
\hline \multirow[t]{3}{*}{$\begin{array}{l}\text { Lichenoid lesions / } \\
\text { erosions / ulcers }\end{array}$} & Rinse & $\begin{array}{c}\text { Clobetasol } \\
\text { Budesonide } \\
\text { Dexamethasone } \\
\text { Tacrolimus } \\
\text { Triamcinolone } \\
\text { Prednisolone } \\
\text { Clobetasol: Tacrolimus } \\
1: 1\end{array}$ & $\begin{array}{c}0.5 \mathrm{mg} / \mathrm{mL}(0.05 \%) \\
0.3 \mathrm{mg} / \mathrm{mL}(0.03 \%) \\
0.1 \mathrm{mg} / \mathrm{mL}(0.01 \%) \\
1 \mathrm{mg} / \mathrm{mL}(0.1 \%) \\
0.1 \mathrm{mg} / \mathrm{mL}(0.01 \%) \\
3 \mathrm{mg} / \mathrm{mL}(0.03 \%) \\
\text { Not specified }\end{array}$ & $\begin{array}{l}\text { Ala } \\
\text { Blla } \\
\text { Alll } \\
\text { Alll } \\
\text { Blla } \\
\text { BIII } \\
\text { CIII }\end{array}$ & \multirow[t]{2}{*}{$\begin{array}{l}\text { Requires } \\
\text { nystatin } \\
\text { prophylaxis } \\
\text { due to the } \\
\text { risk of fungal } \\
\text { infections }\end{array}$} \\
\hline & $\begin{array}{c}\text { Gel, paste, } \\
\text { ointment }\end{array}$ & $\begin{array}{l}\text { Clobetasol gel } \\
\text { Tacrolimus ointment } \\
\text { Fluocinonide gel }\end{array}$ & $\begin{array}{c}0.05 \% \\
0.1 \% \\
0.05 \%\end{array}$ & $\begin{array}{l}\text { Ala } \\
\text { Blla } \\
\text { BIII }\end{array}$ & \\
\hline & $\begin{array}{l}\text { Intralesional } \\
\text { injection }\end{array}$ & Triamcinolone & $40 \mathrm{mg} / \mathrm{mL} ; 0,5 \mathrm{~mL} / \mathrm{cm} 2$ & Cllb & \\
\hline
\end{tabular}




\begin{tabular}{|c|c|c|c|c|c|}
\hline & PUVA/UVB & Psoralen & & Cll & $\begin{array}{l}\text { Refractory } \\
\text { disease }\end{array}$ \\
\hline Mucosal pain & $\begin{array}{c}\text { Rinse } \\
\text { Not applicable }\end{array}$ & $\begin{array}{c}\text { Lidocaine } \\
\text { Kaolin-pectin- } \\
\text { diphenhydramine- } \\
\text { lidocaine } 1: 1: 1 \\
\text { Low power laser } \\
\text { therapy (infrared) for } \\
\text { pain relief }\end{array}$ & $\begin{array}{c}2 \% \\
\text { Not applicable } \\
\text { Not applicable }\end{array}$ & $\begin{array}{l}\text { BIII } \\
\text { BIII } \\
\text { CIII }\end{array}$ & $\begin{array}{l}\text { Do not swollen } \\
\text { lidocaine - risk } \\
\text { for pneumonia }\end{array}$ \\
\hline Xerostomia* & $\begin{array}{l}\text { Toothpaste / } \\
\text { Liquid Gel } \\
\text { Bubble gum } \\
\text { Rinse } \\
\text { Gel or spray } \\
\text { Pills }\end{array}$ & $\begin{array}{l}\text { Sodium fluoride } \\
\text { Salivary stimulants } \\
\text { Water sipping } \\
\text { Oral lubricants } \\
\text { Pilocarpine } \\
\text { Cevimeline }\end{array}$ & $\begin{array}{l}\text { According to the } \\
\text { manufacturer } \\
\text { Per need } \\
\text { Per need } \\
\text { Per need } \\
5-10 \mathrm{mg} \times 3-4 / \mathrm{d} \\
15-30 \mathrm{mg} \mathrm{X} 3 / \mathrm{d}\end{array}$ & $\begin{array}{l}\text { Alb } \\
\text { Alll } \\
\text { Alll } \\
\text { Bll } \\
\text { Blla } \\
\text { Bll }\end{array}$ & \\
\hline
\end{tabular}

Adapted from Carpenter, et al, 2015[6] and Wolff, et al., 2010[39]

\section{ACKNOWLEDGMENTS}

The authors thank the Brazilian Society of Bone Marrow Transplantation for the opportunity to participate in this consensus.

\section{REFERENCES}

1.Abedin S, McKenna E, Chhabra S, Pasquini M, Shah NN, Jerkins J, Baim A, Runaas L, Longo W, Drobyski W, Hari PN, Hamadani M (2019) Efficacy, Toxicity, and Infectious Complications in Ruxolitinib-Treated Patients with Corticosteroid-Refractory Graft-versus-Host Disease after Hematopoietic Cell Transplantation Biol Blood Marrow Transplant v. 25, p. 1689-1694, 2019.

2.Alborghetti MR, Correa ME, Adam RL, Metze K, Coracin FL, de Souza CA, Cintra ML (2005) Late effects of chronic graft-vs.-host disease in minor salivary glands J Oral Pathol Med v.34, p. 486493, 2005.

3.Alborghetti MR, Correa MEP, Whangbo J, Shi X, Aricetti JA, da Silva AA, Miranda ECM, Sforca ML, Caldana C, Gerszten RE, Ritz J, Zeri ACM (2019) Clinical Metabolomics Identifies Blood Serum Branched Chain Amino Acids as Potential Predictive Biomarkers for Chronic Graft vs. Host Disease Front Oncol 9: 141

4.Boer CC, Correa ME, Miranda EC, de Souza CA (2010) Taste disorders and oral evaluation in patients undergoing allogeneic hematopoietic SCT Bone Marrow Transplant v. 45, p. 705-711, 705-711, 2010.

5.Boer CC, Correa ME, Tenuta LM, Souza CA, Vigorito AC (2015) Post-allogeneic Hematopoietic Stem Cell Transplantation (HSCT) changes in inorganic salivary components Support Care Cancer v. 23, p. 2561-2567, 2015.

6.Carpenter $\mathrm{PA}$, Kitko $\mathrm{CL}$, Elad $\mathrm{S}$, Flowers $\mathrm{ME}$, Gea-Banacloche JC, et al. National Institutes of Health Consensus Development Project on Criteria for Clinical Trials in Chronic Graft-versus-Host Disease: V. The 2014 Ancillary Therapy and Supportive Care Working Group Report Biol Blood Marrow Transplant v. 21, p. 1167-1187, 2015.

7.Chaudhry HM, Bruce AJ, Wolf RC, Litzow MR, Hogan WJ, Patnaik MS, Kremers WK, Phillips GL, Hashmi SK (2016) The Incidence and Severity of Oral Mucositis among Allogeneic Hematopoiet- 
ic Stem Cell Transplantation Patients: A Systematic Review Biol Blood Marrow Transplant v. 22, p. 605-616, 2016.

8.Coracin FL, Pizzigatti Correa $\mathrm{ME}$, Camargo $\mathrm{EE}$, Peterson DE, de Oliveira Santos A, Vigorito AC, Borba Oliveira G, de Brito Eid KA, Zulli R, De Souza CA (2006) Major salivary gland damage in allogeneic hematopoietic progenitor cell transplantation assessed by scintigraphic methods Bone Marrow Transplant v. 37, p. 955-959, 2006.

9.Djuric M, Jankovic L, Jovanovic T, Pavlica D, Brkic S, Knezevic A, Markovic D, Milasin J (2009) Prevalence of oral herpes simplex virus reactivation in cancer patients: a comparison of different techniques of viral detection J Oral Pathol Med v. 38, p. 167-173, 2009.

10.Dyer G, Brice L, Schifter M, Gilroy N, Kabir M, Hertzberg M, Greenwood M, Larsen SR, Moore J, Gottlieb D, Huang G, Hogg M, Brown L, Tan J, Ward C, Kerridge I (2018) Oral health and dental morbidity in long-term allogeneic blood and marrow transplant survivors in Australia Aust Dent J 2018.

11.Elad S, Aljitawi O, Zadik Y (2020) Oral graft-versus-host disease: a pictorial review and a guide for dental practitioners Int Dent J

12.Epstein JB, Raber-Durlacher JE, Huysmans MC, Schoordijk MCE, Cheng JE, Bensadoun RJ, Arany PR (2018) Photobiomodulation Therapy Alleviates Tissue Fibroses Associated with Chronic Graft-Versus-Host Disease: Two Case Reports and Putative Anti-Fibrotic Roles of TGF-beta Photomed Laser Surg v. 36, p. 92-99, 2018.

13.Epstein JB, Raber-Durlacher JE, Lill M, Linhares YP, Chang J, Barasch A, Slief RI, Geuke M, Zecha JA, Milstein DM, Tzachanis D (2017) Photobiomodulation therapy in the management of chronic oral graft-versus-host disease Support Care Cancer v. 25, p. 357-364, 2017.

14.Fall-Dickson JM, Pavletic SZ, Mays JW, Schubert MM (2019) Oral Complications of Chronic Graft-VersusHost Disease J Natl Cancer Inst Monogr 2019

15. Haverman TM, Raber-Durlacher JE, Rademacher WM, Vokurka S, Epstein JB, Huisman C, Hazenberg MD, de Soet JJ, de Lange J, Rozema FR (2014) Oral complications in hematopoietic stem cell recipients: the role of inflammation Mediators Inflamm . p. 378281, 2014.
16. Horn TD, Rest EB, Mirenski Y, Corio RL, Zahurak $M L$, Vogelsang GB (1995) The significance of oral mucosal and salivary gland pathology after allogeneic bone marrow transplantation Arch Dermatol. v. 131, p. 964-965,1995

17.Imanguli MM, Atkinson JC, Harvey KE, Hoehn GT, Ryu OH, Wu T, Kingman A, Barrett AJ, Bishop MR, Childs RW, Fowler DH, Pavletic SZ, Hart TC (2007) Changes in salivary proteome following allogeneic hematopoietic stem cell transplantation Exp Hematol v. 35, p. 184-192, 2007.

18.Ion D, Stevenson K, Woo SB, Ho VT, Soiffer R, Antin JH, Treister NS (2014) Characterization of oral involvement in acute graft-versus-host disease Biol Blood Marrow Transplant v. 20, p. 1717-1721, 2014.

19.Jagasia MH, Greinix HT, Arora M, Williams KM, et al.(2015) National Institutes of Health Consensus Development Project on Criteria for Clinical Trials in Chronic Graft-versus-Host Disease: I. The 2014 Diagnosis and Staging Working Group report Biol Blood Marrow Transplant v. 21, p. 389401 e 381, 2015.

20.Khoury HJ, Langston AA, Kota VK, Wilkinson JA, Pusic I, Jillella A, Bauer S, Kim AS, Roberts D, AlKadhimi Z, Bodo I, Winton E, Arellano M, DiPersio JF (2018) Ruxolitinib: a steroid sparing agent in chronic graft-versus-host disease Bone Marrow Transplant v. 53, p. 826-831, 2018.

21.Kuten-Shorrer M, Woo SB, Treister NS (2014) Oral graft-versus-host disease Dent Clin North Am v. 58, p. 351-368, 2014.

22.Lee SJ, Wolff D, Kitko C, Koreth et al. (2015) Measuring therapeutic response in chronic graft-versus-host disease. National Institutes of Health consensus development project on criteria for clinical trials in chronic graft-versus-host disease: IV. The 2014 Response Criteria Working Group report Biol Blood Marrow Transplant v. 21, p. 984-999, 2015.

23.Lofgren CD, Wickstrom C, Sonesson M, Lagunas PT, Christersson C (2012) A systematic review of methods to diagnose oral dryness and salivary gland function BMC Oral Health v. 12, p. 29, 2012.

24.Martin PJ, Lee SJ, Przepiorka D, et al. (2015) National Institutes of Health Consensus Development Project on Criteria for Clinical Trials in Chronic Graft-versus-Host Disease: VI. The 2014 
Clinical Trial Design Working Group Report Biol Blood Marrow Transplant v. 21, p. 1343-1359, 2014.

25.Mawardi H, Elad S, Correa ME, Stevenson K, Woo SB, Almazrooa S, Haddad R, Antin JH, Soiffer R, Treister N (2011) Oral epithelial dysplasia and squamous cell carcinoma following allogeneic hematopoietic stem cell transplantation: clinical presentation and treatment outcomes Bone Marrow Transplant v. 46, p. 884-891, 2011.

26.Mays JW, Fassil H, Edwards DA, Pavletic SZ, Bassim CW (2013) Oral chronic graft-versus-host disease: current pathogenesis, therapy, and research Oral Dis v. 19, p. 327-346, 2013.

27.Noce CW, Gomes A, Shcaira V, Correa ME, Moreira MC, Silva Junior A, Goncalves LS, Garnica M, Maiolino A, Torres SR (2014) Randomized double-blind clinical trial comparing clobetasol and dexamethasone for the topical treatment of symptomatic oral chronic graft-versus-host disease Biol Blood Marrow Transplant v. 20, p. 1163-1168, 2014.

28.Petti S, Polimeni A, Berloco PB, Scully C (2013) Orofacial diseases in solid organ and hematopoietic stem cell transplant recipients Oral Dis v. 19, p. 18-36, 2013.

29.Picardi A, Ferraro AS, Miranda M, Meconi F, Lanti A, Adorno G, Arcese W, Bollero P (2017) Therapeutic efficiency of platelet gel for the treatment of oral ulcers related to chronic graft versus host disease after allogeneic haematopoietic stem cell transplantation Oral Implantol (Rome) v. 10, p. 398-405, 2017.

30. Ramos GA, Moreira MCR, Costa A, Antunes HS (2020) Photobiomodulation Therapy and Dexamethasone in the Management of Oral Acute Graft-Versus-Host Disease: Case Report Photobiomodul Photomed Laser Surg v. 38, p. 683686, 2020.

31.Santos-Silva AR, Feio Pdo S, Vargas PA, Correa ME, Lopes MA (2015) CGVHD-Related Caries and Its Shared Features with Other 'Dry-Mouth'-Related Caries Braz Dent J v.26, p. 435-440, 2015.
32.Schubert MM, Correa ME (2008) Oral graft-versushost disease Dent Clin North Am v. 52, p. 79-109, 2008.

33.Scordo M, Shah GL, Kosuri S, Herrera DA, Cho C, Devlin SM, Maloy MA, Nieves J, Borrill T, Avecilla ST, Meagher RC, Carlow DC, et al. Effects of Late Toxicities on Outcomes in Long-Term Survivors of Ex-Vivo CD34(+)-Selected Allogeneic Hematopoietic Cell Transplantation Biol Blood Marrow Transplant v. 24, p. 133-141, 2018.

34.Soares $A B$, Faria PR, Magna LA, Correa ME, de Sousa CA, Almeida OP, Cintra ML (2005) Chronic GVHD in minor salivary glands and oral mucosa: histopathological and immunohistochemical evaluation of 25 patients J Oral Pathol Med v. 34, p. 368-373, 2005.

35.Treister N, Duncan C, Cutler C, Lehmann L (2012) How we treat oral chronic graft-versus-host disease Blood v. 120, p. 3407-3418, 2012.

36.van der Beek MT, Laheij AM, Raber-Durlacher JE, von dem Borne PA, Wolterbeek R, van der Blijde Brouwer CS, van Loveren C, Claas EC, Kroes AC, de Soet JJ, Vossen AC (2012) Viral loads and antiviral resistance of herpesviruses and oral ulcerations in hematopoietic stem cell transplant recipients Bone Marrow Transplant v. 47, p. 12221228, 2012.

37.van der Beek MT, Vermont CL, Bredius RG, Marijt EW, van der Blij-de Brouwer CS, Kroes AC, Claas EC, Vossen AC (2013) Persistence and antiviral resistance of varicella zoster virus in hematological patients Clin Infect Dis n.56, p. 325-343.

38.Vokurka S, Svoboda T, Karas M, Koza V, Jindra P, Kazakov D, Boudova L (2011) Significant oral graft-versus-host disease after allogeneic stem cell transplantation with the FLU/MEL conditioning regimen Med Sci Monit v. 17, p. 480-484, 2011.

39.Wolff D, Bertz H, Greinix H, Lawitschka A, Halter J, Holler E (2011) The treatment of chronic graft-versus-host disease: consensus recommendations of experts from Germany, Austria, and Switzerland Dtsch Arztebl Int v.108, p. 732-740, 2011. 